Hasian Laurentius Tonggo, Irwansyah:

Mediated Catholic Mass During the COVID-19 Pandemic: On Communication, Technology and Spiritual Experience

Misa Katolik Termediasi Saat Pandemi COVID-19: Antara Komunikasi, Teknologi, dan Pengalaman Spiritual

\title{
Mediated Catholic Mass During the COVID-19 Pandemic: On Communication, Technology and Spiritual Experience
}

\section{Misa Katolik Termediasi Saat Pandemi COVID-19: Antara Komunikasi, Teknologi, dan Pengalaman Spiritual}

\author{
Hasian Laurentius Tonggo ${ }^{1}$, Irwansyah ${ }^{2}$ \\ ${ }^{1}$ Departemen Ilmu Komunikasi, Fakultas Ilmu Sosial dan Ilmu Politik, Universitas Indonesia, \\ Salemba, Jakarta Pusat, Indonesia* \\ Email: hasian.laurentius@ui.ac.id \\ ${ }^{2}$ Departemen Ilmu Komunikasi, Fakultas Ilmu Sosial dan Ilmu Politik, Universitas Indonesia, \\ Salemba, Jakarta Pusat, Indonesia \\ Email:dr.irwansyah.ma@gmail.com
}

Masuk tanggal : 30-10-2020, revisi tanggal : 03-02-2021, diterima untuk diterbitkan tanggal : 11-02-2021

\begin{abstract}
The COVID-19 pandemic has prompted Catholic churches in Indonesia to conduct physical distancing, close their doors and move mass to online media or television. This situation is something extraordinary for the Catholic church which is known to adhere to tradition in the implementation of its worship. This study aims to determine the experience of Catholics in conducting mediated worship using Religious-Social Shaping of Technology examining and concepts, namely social affordance, religion-online/onlinereligion, and digital media law. This qualitative research is done by interviewing six informants using descriptive phenomenological approach. The results of the study indicate four main findings. First, informants have the freedom to choose the tools or channels to attend the mediated mass. Second, the interactivity in the mediated mass is lost. Third, the atmosphere of the mediated mass can have an impact on the solemnity of worship. Fourth, the use of technology for mediated mass cannot absolutely be paralleled with physical worship, but some informants still hope that the mediated mass will be held after this pandemic. This research concludes that mediated mass during a pandemic is not as ideal as a physical mass because the experience gained is not optimal, but it opens up wider opportunities to reach people who may not be physically present in church from anywhere. Academically, this research is expected to increase the wealth of knowledge about mediated worship during a pandemic. Meanwhile, in practical terms, this research can be a reference for the church to improve its overall quality.
\end{abstract}

Keywords: COVID-19 pandemic, Catholic, live streaming, mediated mass

\begin{abstract}
Abstrak
Pandemi COVID-19 membuat gereja Katolik di Indonesia melakukan physical distancing bahkan menutup pintunya dan mengalihkan misa ke media daring atau televisi. Keadaan ini merupakan sesuatu yang luar biasa bagi gereja Katolik yang terkenal memegang teguh tradisi dalam pelaksanaan ibadahnya. Penelitian ini memiliki tujuan yaitu ingin mengetahui pengalaman umat Katolik dalam melakukan ibadah termediasi dengan menggunakan Religious-Social Shaping of Technology serta beberapa konsep lain, yaitu social affordance, religion-online/online-religion, dan hukum media digital. Adapun
\end{abstract}


pelaksanaan penelitian kualitatif ini adalah dengan mewawancarai enam informan menggunakan pendekatan fenomenologi deskriptif. Hasil penelitian ini menunjukkan empat temuan utama. Pertama, informan memiliki kebebasan untuk memilih alat maupun kanal untuk mengikuti misa termediasi. Kedua, interaktivitas dalam misa termediasi menjadi hilang. Ketiga, suasana misa termediasi bisa berdampak pada kekhusyukan saat beribadah. Keempat, pemanfaatan teknologi untuk misa termediasi memang tidak bisa mutlak disejajarkan dengan ibadah fisik namun sebagian informan tetap mengharapkan misa termediasi dilakukan setelah masa pandemi ini. Penelitian ini menyimpulkan bahwa misa termediasi selama pandemi memang tidak seideal misa fisik karena pengalaman yang diraih tidaklah maksimal, namun membuka peluang lebih luas untuk menjangkau orang-orang yang tidak mungkin hadir secara fisik di gereja dari mana saja. Secara akademis penelitian ini diharapakan dapat meningkatkan khazanah pengetahuan tentang ibadah termediasi pada saat pandemi. Sementara secara praktis, penelitian ini dapat menjadi acuan bagi gereja untuk meningkatkan kualitas secara menyeluruh.

Kata Kunci: Katolik, live streaming, misa termediasi, pandemi COVID-19

\section{Pendahuluan}

Virus Corona membawa penyakit menular yang pertama kali ditemukan pada akhir 2019 di Wuhan, Provinsi Hubei, Cina. Virus tersebut kemudian menyebar ke negara lain di seluruh dunia. Dalam tiga bulan pertama tahun 2020, penyakit itu berhasil melanda seluruh dunia, membunuh ribuan orang, dan membuat lainnya terinfeksi dan terbaring di tempat tidur (Guo et al., 2020; Shereen et al., 2020). Pada 2 Maret 2020, dua warga Depok, Jawa Barat dinyatakan positif tertular Virus Corona atau COVID-19 (Putri, 2020). Kejadian tersebut jadi titik awal penyebaran Virus Corona masuk Indonesia yang mengundang reaksi masyarakat. Seiring bertambahnya angka pasien yang tertular, pada 15 Maret 2020, Presiden Joko Widodo secara resmi menghimbau masyarakat untuk bekerja, belajar, dan beribadah dari rumah. Dari beberapa kasus yang ada di luar negeri, dapat dikatakan bahwa kegiatan umat beragama dapat berdampak langsung terhadap penyebaran virus, baik dengan cara menghambat maupun mempercepat penularan secara sosial (Wildman et al., 2020). Sejak kemunculan COVID-19 frasa "Stay at home"-versi Indonesia "dirumah aja"menjadi umum ditemukan sebagai strategi untuk mengurangi peluang eksposur manusia kepada virus (Isiko, 2020).

Gereja-gereja Katolik di Indonesia pun menanggapi hal yang sama dengan segera mengirimkan surat pastoral kepada para anggotanya yang menyatakan bahwa tidak akan ada kebaktian fisik, termasuk sakramen seperti baptisan, ekaristi, bahkan pernikahan, hingga pemberitahuan lebih lanjut. Orang-orang juga didorong untuk mengikuti misa dari rumah. Mereka dapat melakukannya dengan menonton siaran live streaming dari berbagai saluran YouTube yang disediakan oleh berbagai gereja Katolik di seluruh Indonesia atau dengan menonton siaran langsung misa Katedral Jakarta di TVRI (Televisi Republik Indonesia). Live streaming pertama di TVRI berlangsung pada Minggu, 29 Maret 2020 (Chrisyantia, 2020). Maka mentransfer gereja secara termediasi internet atau media lain menjadi pilihan dimana melibatkan penyiaran langsung layanan ibadah 
Hasian Laurentius Tonggo, Irwansyah:

Mediated Catholic Mass During the COVID-19 Pandemic: On Communication, Technology and Spiritual Experience

Misa Katolik Termediasi Saat Pandemi COVID-19: Antara Komunikasi, Teknologi, dan Pengalaman Spiritual

tradisional sambil mencoba untuk meniru tampilan dan nuansa pertemuan mingguan semirip mungkin (H. Campbell, 2020). Para pastor dan pendeta memfilmkan diri mereka sendiri dalam tempat suci tanpa jemaat sambil membacakan liturgi bacaan atau berkhotbah yang sama bilamana saat sebelum pandemi (H. Campbell, 2020).

Misa adalah bagian dari rangkaian ritus Katolik. Ritual, menurut Durkheim, aturan perilaku yang mengatur bagaimana hal-hal sakral harus dilakukan oleh seseorang (M. A. Hidayat, 2017). Ini juga merupakan ritual yang bisa dilihat sebagai bentuk komunikasi sebagaimana James Carey memperkenalkan konsep pandangan ritual komunikasi (Radford, 2005). Menurut Carey, pandangan ritual komunikasi memiliki keterkaitan yang erat dengan konsep berbagi, partisipasi, dan pergaulan, bukan hanya sebagai bentuk transmisi pesan dari komunikator kepada komunikan saja. Makna diambil dari akar kata komunikasi, yaitu kesamaan (kesamaan), persekutuan (berbagi atau bertukar pikiran dan perasaan yang intim dalam suasana spiritual), dan komunitas (komunitas, kebersamaan) (Radford, 2005). Carey mengatakan bahwa komunikasi sebagai ritual tidak terfokus pada transfer pesan dalam suatu ruang tetapi pada penguatan masyarakat pada waktunya; bukan tindakan berbagi informasi tetapi representasi dari keyakinan yang sama. Pola dasar komunikasi di sini tidak terbatas pada pengiriman pesan kepada penerima tetapi upacara sakral yang mampu mengumpulkan orang dalam persekutuan dan kesetaraan, seperti persekutuan pada saat Misa Ekaristi. Dalam pandangan ritual, urgensi ditempatkan pada peran doa komunitas, nyanyian, dan upacara; dan bukan pendeta yang melayani jamaah (Radford, 2005). Dengan kata lain, komunikasi dan relasi sosial merupakan ciri fundamental sebuah agama. Agama berusaha menghubungkan manusia dengan sesuatu yang transenden dan melalui organisasi hubungan sosial transenden ini, orang-orang bersatu (Lövheim, 2011).

Artikel ini menggunakan teori Religious-Social Shaping of Technology (RSST) yang diperkenalkan oleh Campbell (2010). Teori ini menyingkap cara untuk mengamati bagaimana individu atau kelompok agama menolak, menerima atau menegosiasikan penggunaan teknologi yang berkaitan dengan kode moral, nilai, kepercayaan, dan tradisi kelompok. Pendekatan RSST berangkat dari pada teori Social Shaping of Technology (SST), yaitu mengamati proses interaksi antara manusia dan teknologi sebagai bentuk individu negosiasi teknologi dalam kehidupan sehari-hari (Campbell, 2010). RSST ini melihat bahwa sistem kepercayaan dan makna yang dirasakan oleh individu atau kelompok mengenai teknologi mempengaruhi cara mereka memilih dan menggunakan teknologi dalam situasi sosial tertentu (Humeira \& Sarwono, 2019), dalam hal ini situasi pandemi. Selain RSST, penelitian ini juga menggunakan beberapa konsep yang lain.

Misa yang dimediasi merupakan salah satu bentuk media audiovisual. Menurut Robertson, audiovisual merupakan interaksi antara gambar, suara dan musik (Pradsmadji \& Irwansyah, 2019). Dalam misa yang dimediasi, umat membutuhkan perangkat digital atau elektronik untuk mengakses konten audiovisual yaitu misa. Perayaan misa menggunakan perantara media elektronik atau digital seperti streaming sendiri sebenarnya bukanlah sesuatu yang sama sekali baru. Streaming adalah proses transfer data atau informasi dari satu 
pengguna ke pengguna lainnya, baik melalui aplikasi khusus maupun langsung tanpa perlu mengunduh konten (Baktikominfo, 2019). Ada dua jenis streaming yaitu prerecorded streaming dan live streaming. Gereja Katolik biasanya mengalirkan misa yang dimediasi secara langsung. Dalam live streaming, pemilik konten merekam videonya dan menayangkannya langsung di media, seperti televisi atau Internet. Penonton dapat menonton setiap detik streaming dari pemilik konten secara langsung (Baktikominfo, 2019). Ada enam karakteristik live streaming video, yaitu (1) komunikasi audiovisual, (2) akses konstan, (3) real-time, (4) ephemeral, (5) unedited, dan (6) ubiquitous. Dalam konteks pertunjukan, live streaming tidak ditujukan untuk menggantikan pertunjukan langsung, tetapi untuk memperpanjang pengalaman (Lim, 2020). Perspektif ini juga dapat diterapkan untuk massa yang dimediasi, asalkan dilihat sebagai semacam pertunjukan yang disiarkan secara daring atau luring kepada jemaat. Teknologi memediasi ruang-ruang media tempat praktik keagamaan dan spiritual berdiam dan mengubahnya sebagai ruang sakral, ruang publik, ruang komunal atau secara bersamaan (Lim, 2019).

Digitalisasi itu sendiri tidak hanya mengubah tanda-tanda media audiovisual, karena penting agar video menjadi portabel, tetapi juga mengubah perilaku penonton (Mikos, 2016). Salah satu bentuk kemunculan media digital adalah YouTube. Dalam sebuah video YouTube pada umumnya terdapat fitur interaktif yang memungkinkan penonton memberikan feedback. Kemampuan audiens untuk memberikan umpan balik, seperti berkomentar, menyukai, dan berbagi adalah contoh social affordances. Keterjangkauan terjadi ketika properti suatu objek bersinggungan dengan kemampuan agen sosial (Cabiddu et al., 2014), misalnya teknologi televisi atau internet memiliki fitur yang memungkinkan umat Katolik menemukan dan menonton live streaming misa. Social affordance adalah kualitas sebuah artefak fisik atau virtual yang mengundang atau memfasilitasi interaksi antarkhalayak dalam media baru (Kavanaugh et al., 2014). Social affordance membuat khalayak menyadari opini dan keberadaan orang lain di dunia daring (Kavanaugh et al., 2014) sehingga mendukung manfaat agama untuk membangun koneksi atau relasi sosial (Lövheim, 2011).

Sementara itu, untuk penayangan misa di televisi, muncul pertanyaan secara teologis, yaitu kemampuannya untuk mempertahankan kekhusyukan perayaan secara liturgis dalam misa. Adapun dari perspektif studi media, pertanyaan utamanya adalah tentang "sifat" atau kualitas partisipasi penonton dalam misa yang disiarkan televisi (Zordan, 2014). Penayangan misa melalui televisi memiliki sejumlah fitur dan karakteristik yang mirip dengan acara media lainnya, yaitu sebagai sebuah acara yang terencana, terselenggara secara independen dari media dan disiarkan langsung dari lokasi terpencil (Zordan, 2014). Meski begitu media berfungsi mengkomunikasikan pesan Injil dan bekerja sebagai alat untuk menjangkau lebih banyak orang dan melintasi batas-batas pertemuan tradisional orang-orang di gereja untuk mendengarkan Firman Tuhan (Nduka \& McGuire, 2017).

Dalam Bills (2017), Gereja Katolik menyatakan bahwa penggunaan ruang virtual untuk beribadah dengan sendirinya tidak cukup dan hanya digunakan sebagai pelengkap tradisional praktik gereja. Meski demikian, peran komunikasi 
Hasian Laurentius Tonggo, Irwansyah:

Mediated Catholic Mass During the COVID-19 Pandemic: On Communication, Technology and Spiritual Experience

Misa Katolik Termediasi Saat Pandemi COVID-19: Antara Komunikasi, Teknologi, dan Pengalaman Spiritual

digital yang terus berkembang dalam masyarakat kontemporer memaksa para pengkaji Katolik untuk mempertimbangkan kemungkinan memperluas dan membaurkan pengalaman tradisional ke ranah digital (Bills, 2017). Saat ini Gereja Katolik mulai beraktifitas secara daring pada awal tahun 1990-an dan menyambut dunia digital sebagai forum pewartaan baru (Guzek, 2015). Takhta Suci Vatican sebagai otoritas agama Katolik dunia saat ini mengelola 78 situs termasuk di antaranya laman Facebook, profil Twitter, dan dua aplikasi resmi (Giorgi, 2019). Ini menunjukkan organisasi keagamaan mulai merangkul media baru sebagai cara berkomunikasi dan memperluas jangakauan ibadah (Ratcliff et al., 2017).

Højsgaard \& Warburg (dalam Frost \& Youngblood, 2014) mengatakan bahwa internet dan keniscayaannya pada teks media menimbulkan pertanyaan apakah pengalaman relijius bisa dibentuk dari kata-kata semata. Internet dianggap tidak mampu memediasi pengalaman reliji karena fokus pada penglihatan, imaji, teks, individualistik, dan medium yang terpisah. Selain itu Jay Kinney (dalam Hagenbuch, 2020) menganggap internet tidak kompatibel dengan kebutuhan kontemplasi soliter dan pelepasan sosial yang menjadi ajaran penentu sebagian besar tradisi agama guna mencapai perkembangan reliji.

Sementara itu, studi lain menilai ibadah termediasi sebagai hal positif, misalnya fakta internet telah melekat di kehidupan sehari-hari, di mana aktivitas daring dan luring terintegrasi. Daring memungkinkan kelompok luring untuk memperluas interkasi antaranggota dan struktur, serta membuka ruang eksperimen komunikasi dan hubungan yang bisa memperkuat atau mengurangi kedua konteks itu. Pelayanan ibadah gereja daring membantu konsolidasi dan keanggotaan umat (H. A. Campbell \& DeLashmutt, 2014).

Helland (dalam Frost \& Youngblood, 2014) memperkenalkan istilah Religion-Online/Online-Religion sebagai tipologi yang membedakan dua aktivitas agama di dunia maya. Religion-online mempertahankan struktur melalui komunikasi one-to-many yang terkontrol sementara online-religion mendorong kebebasan interaksi tingkat akar rumput (Frost \& Youngblood, 2014). Kala pandemi ini, kebanyakan gereja Katolik menerapkan konsep religion-online karena menampilkan prosesi misa yang sama dengan misa fisik, yaitu seorang pastor dan beberapa pembantunya memimpin misa dan para umat dihimbau untuk duduk diam menyaksikan dari layar.

Perpindahan misa fisik ke termediasi baik secara daring atau dari televisi membuat kegiatan misa umat Katolik masuk ke ranah media digital dan non digital. Dalam kaitannya dengan media digital, Logan (2019) memperkenalkan Hukum Media Digital sebagai teknik analisis yang merupakan pengembangan dari Hukum Media Marshall McLuhan. Adapun empat poin Hukum Media Digital tersebut, yakni:(1) media baru digital memperkuat interaktivitas, akses pada informasi, dan komunikasi dua arah, (2) membuat media massa seperti televisi dan surat kabar menjadi kuno, (3) memulihkan komunitas, dan (4) jika didorong cukup jauh, media akan berputar atau berbalik ke arah hiperealitas atau hilangnya kontak dengan alam dan tubuh manusia (Logan, 2019).

Kebaruan penelitian ini terletak pada konteks Indonesia dan relevansinya dengan waktu, karena penelitian sebelumnya yang disebutkan di atas mengenai live streaming misa atau ibadah lainnya dilakukan di luar negeri dan tidak 
dilakukan pada saat terjadi pandemi. Dalam pandemi ini, penonton Katolik menggunakan media audiovisual untuk bergabung dalam misa sekaligus mendapatkan pengalaman spiritual. Berangkat dari hal tersebut, penelitian ini mengajukan pertanyaan: bagaimana pengalaman umat Katolik saat menghadiri misa yang dimediasi? Penelitian ini bertujuan untuk menggali dan memahami pengalaman yang didapat umat Katolik ketika mengikuti misa yang dimediasi. Penelitian ini juga melihat secara khusus misa Katolik sebagai salah satu bentuk komunikasi yang jarang dibahas dalam penelitian ilmiah di Indonesia.

\section{Metode Penelitian}

Dengan berdasarkan pada paradigma konstruksionisme yang menekankan subjektifitas dan refleksifitas (D. Hidayat, 2009), penelitian ini menggunakan pendekatan kualitatif karena melibatkan kasus dan konteks, memeriksa proses dan kasus sosial dalam konteks sosial, dan interpretasi penelitian atau makna dalam tatanan sosial budaya tertentu (Neuman, 2014). Peneliti diajak memeriksa kehidupan sosial dari beberapa sudut pandang dan cara orang membentuk identitas (Neuman, 2014). Kemudian penelitian ini menggunakan strategi fenomenologi karena mencoba untuk menggali sebuah fenomena dari pengalaman nuansa individu, landasan kontekstual, emosi, serta tindakan yang ditimbulkan dalam kesadaran (Christensen et al., 2017).

Unit analisis penelitian ini adalah individu, yaitu umat Katolik yang mengakses media televisi atau internet guna mengikuti misa jarak jauh. Peneliti berusaha memahami bagaiamana umat katolik memaknai misa termediasi sebagai bentuk kegiatan beribadah di masa pandemi. Guna mengetahui pengalamana informan, peneliti melakukan wawancara semi-terstruktur karena jenis pertanyaan yang diberikan mencakup aspek pengalaman yang ingin dieksplorasi tetapi sifatnya luwes sehingga peneliti bisa menyesuaikan arah pertanyaan sesuai dengan jawaban informan (Landridge, 2007).

Para informan dalam peneltian ini ditentukan secara purposive sampling. Adapun kriteria-kriteria informan, yaitu (1) telah dibaptis secara Katolik dan terdaftar sebagai umat salah satu Gereja Katolik, (2) telah mengikuti misa daring atau televisi minimal tiga kali selama Pandemi COVID-19 secara konsisten, (3) usia diatas 21 tahun, (4) mengakses misa melalui gawai atau televisi milik pribadi, (5) bersedia meluangkan waktu wawancara dengan penulis tanpa imbalan. Seluruh informan memenuhi kriteria-kriteria diatas. Informan E baru memeluk agama Katolik sejak tahun 2018 dan terdaftar sebagai umat di Gereja Katedral Bogor. Informan K, C, dan S terdaftar di gereja stasi St. Laurensius Parung Panjang, Kabupaten Bogor. Informan J pada kondisi normal kerap bergereja di St. Monica Bumi Serpong Damai, Tangerang. Sementara Informan A saat ini bergereja di Pangkal Pinang, Kepulauan Riau. Informan memiliki umur yang beragam, yaitu dari 23 s.d. 61 tahun sehingga mewakili kelas umur umat dewasa.

Pengumpulan data penelitian dilakukan dengan mewawancarai enam informan melalui sambungan telepon mengingat situasi pandemi yang terjadi selama penelitian ini berlangsung. Wawancara memiliki kekuatan data naratif, sehingga peneliti bisa menginvestigasi orang lebih mendalam. Peneliti 
Hasian Laurentius Tonggo, Irwansyah:

Mediated Catholic Mass During the COVID-19 Pandemic: On Communication, Technology and Spiritual Experience

Misa Katolik Termediasi Saat Pandemi COVID-19: Antara Komunikasi, Teknologi, dan Pengalaman Spiritual

menyiapkan daftar pertanyaan yang berfungsi sebagai basic-checklist untuk memberi ruang pengembangan sambil menjaga proses wawancara tetap sesuai dengan tujuan penelitian (Alshenqeeti, 2014). Data wawancara kemudian diolah atau di-coding yang meliputi tahapan open coding, yaitu pengkodean dari pemahaman yang belum jelas kedalam beberapa kategori relevan. Axial coding, yaitu melacak hubungan antara elemen-elemen data yang dikode. Serta proses menggabungkan dan menyaring kategori sehingga semua kategori berkaitan dengan kategori utama atau selective coding (Neuman, 2014).

\section{Hasil Penemuan dan Diskusi}

Pada situasi normal, gereja Katolik melaksanakan pelayanan ibadah misa kepada para umat secara langsung. Waktu misa yang paling umum diketahui, bahkan oleh penganut agama lain, adalah misa hari Minggu. Padahal pelaksanaan misa tidak mutlak di hari Minggu pagi saja, ada juga di hari Jumat Pertama, Sabtu Sore, Minggu Sore, dan pada hari-hari besar lain. Idealnya penganut agama katolik mendatangi gereja untuk mengikuti misa seminggu sekali karena Misa atau Sakramen Ekarisiti memiliki fungsi sangat penting dan merupakan pusat serta puncak kehidupan gereja bagi umat Katolik.

\section{Pemilihan dan Penerimaan Teknologi}

Di tengah kondisi physical distancing, umat Katolik bisa mengikuti misa live streaming di YouTube atau di tayangan TVRI. Berikut data partisipasi misa para informan :

Tabel 1. Cara Mengikuti Misa

\begin{tabular}{llcc}
\hline No. & \multicolumn{1}{c}{ Informan } & Cara & Media Pendukung \\
\cline { 3 - 4 } 1. & E, Wanita, 35, Jakarta & Live Streaming & TV \\
2. & K, Wanita, 61, Kab. Bogor & Live Streaming & Laptop \\
3. & C, Pria, 51, Kab. Bogor & TVRI & TV \\
4. & J, Wanita, 23, Tangerang & Live Streaming & Laptop, SMART TV \\
5. & S, Wanita, 26, Kab. Bogor & Live Streaming & Ponsel, Laptop, Headset \\
6. & A, Pria, 35, Pangkal Pinang & Live Streaming & Ponsel, Earphone \\
\hline
\end{tabular}

Tabel tersebut menunjukkan mayoritas informan mengikuti misa secara live streaming dari YouTube yang membutuhkan koneksi internet. Media yang dipakai untuk live streaming adalah SMART TV atau TV dengan adaptor Google Chromecast berkoneksi internet, ponsel atau laptop yang dilengkapi dengan alat bantu dengar seperti earphone atau headset untuk meningkatkan penerimaan suara. Streaming di medium TV dilakukan untuk meraih tampilan visual yang lebih besar.

Selain itu para informan memilih sebuah kanal YouTube untuk misa terkait domisili mereka, misalnya Informan K, C, dan S di kanal Katedral Bogor karena merasa sebagai umat terdaftar dan akrab dengan tata cara misa di gereja yang bersangkutan. Sementara itu, Informan A mengikuti misa dari katedral Pangkal Pinang, Kepulauan Riau, sesuai area wilayah Ia berada saat ini. Informan J mengikuti misa live streaming dari Katedral Jakarta karena disajikan dengan 
lebih profesional, seperti kualitas gambar dan suara yang lebih jernih, sementara Informan E memilih kanal yang sama karena pilihan waktu misa lebih banyak. Live streaming memungkinkan para informan leluasa mencari waktu misa yang cocok, misalnya ketika Informan $\mathrm{K}$ yang harus merawat suaminya yang sedang sakit dan tidak bisa mengikuti misa dari kanal Keuskupan Bogor. Sementara Informan $\mathrm{E}$ dan $\mathrm{A}$ justru terkadang berpindah kanal ketika misa sedang berlangsung bilamana misa tersebut kurang menarik atau sekadar ingin membanding-bandingkan dengan misa di kanal lainnya.

Berbeda dengan yang lain, Informan $\mathrm{C}$ selama ini mengikuti misa dari TVRI yang tayang sekali di hari Minggu. Informan C mengungkapkan:

"Kita pakai TVRI agar bisa dinikmati semuanya, istri dan anak. Kalau anak saya kan lebih familiar dengan laptop. Jadi dari TVRI setiap hari Minggu, kadang jam 11 kadang jam 10 karena lebih gampang saja dan langsung dari Katedral Jakarta. Ya selama ini belum pernah ikut misa live streaming, lewat TVRI saja. Kalau saya merasakan sudah merupakan bagian hidup Katolik ya karena setiap hari Minggu kita biasanya ke gereja. Kini dipermudah siaran langsung di TVRI makanya kita sempatkan waktu ya." (Hasil wawancara pada 22 Mei 2020)

Mengikuti misa live streaming dari kanal YouTube membuat Informan E memperhatikan suatu hal, yakni sejumlah pengelola kanal gereja meniadakan fitur interaktivitas seperti menyukai, berkomentar, dan berbagi selama misa berlangsung. Informan E mengatakan bahwa hal itu memang sudah didesain. Bagi Informan E kemampuan interaktif sebuah kanal penting sebagai cara khalayak memberi kritik masukan kepada pengelola kanal. Namun kala mengikuti misa streaming dari gereja Katolik di Alam Sutera yang membuka kolom chat, ia mengaku tidak memanfaatkan fitur tersebut. Hal yang sama juga ditemui di kanal gereja yang biasa Informan A ikuti, ia tidak pernah menyukai atau berkomentar selama misa livestreaming berlangsung karena baginya hal itu sesuatu yang tak perlu dan tak ia perhatikan. Sementara Informan $S$ mengatakan bahwa kemampuan interaktivitas kanal misa live streaming yang ia ikuti memang sengaja di non-aktifkan.

Informan E, J, S merasa misa live streaming kurang memuaskan karena cara misa ini memerlukan pengondisian suasana, niat, dan tempat yang harus dibuat sendiri. Tidak adanya umat lain membuat Informan $\mathrm{E}$ dan $\mathrm{J}$ kurang fokus. Bagi Informan S, ketiakpuasan dirinya adalah tidak bisa menyaksikan konsekrasi (penyucian hosti) secara langsung serta mendapatkan hosti. Sementara itu, Informan E kadang merasa kurang puas dengan substansi khotbah Pastor dan bacaan injil serta lirik nyanyian yang tidak konsisten. Informan E mengatakan:

"Apa ya ...nggak enaknya ... dari cara ngebacainnya (tertawa). Terus dari khotbahnya.

Nggak sih, khotbahnya kan terakhir kan. Itu aja sih. Terus kadang ada yang dikasih, pas lagi nyanyian, ada yang dikasih teks ada yang nggak, gitu kan. Kayaknya lebih enak... seperti bagaimana sih kita lebih senang hubungan fisik secara langsung ketimbang virtual, bukan?" (Hasil wawancara pada 22 Mei 2020)

Lain halnya dengan Informan $\mathrm{K}$ yang merasa senang dan menikmati misa live streaming karena percaya Tuhan selalu hadir di mana saja. Bagi Informan K, Tuhan bisa hadir di mana pun kita berada. Sama halnya dengan Informan A yang 
Hasian Laurentius Tonggo, Irwansyah:

Mediated Catholic Mass During the COVID-19 Pandemic: On Communication, Technology and Spiritual Experience

Misa Katolik Termediasi Saat Pandemi COVID-19: Antara Komunikasi, Teknologi, dan Pengalaman Spiritual

juga puas dengan misa livestreaming karena lebih mendapatkan privasi yang didukung penggunaan earphone. Ia lebih nyaman bergereja seperti ini karena memberi sensasi baru serta menyadari bahwa misa dapat dilakukan secara jarak jauh. Informan A mengatakan:

"Timbul kesadaran bahwa ini merupakan cara lain beribadah. Kalau gue senengseneng aja online, privatnya lebih dapet apalagi pake earphone. Sensasi baru aja. Gue lebih nyaman kalau gereja begini, ternyata bisa ya jarak jauh, itu sih. Gue juga sejak lulus kuliah udah engga aktif kegiatan gereja kan." (Hasil wawancara pada 22 Mei 2020)

Ketika menyaksikan tayangan visual misa termediasi yang penuh keterbatasan, Informan $\mathrm{E}$ dan $\mathrm{S}$ merasakan perbedaan dari misa fisik yang kaya simbol seperti halnya komuni kudus. Bagi Informan $\mathrm{S}$, misa live streaming mereduksi makna konsekrasi komuni menjadi sekadar tontonan saja. Senada, menurut Informan $\mathbf{J}$, tayangan video saja kurang memberikan rasa sama dibandingkan penghayatan misa fisik.

Sementara Informan $\mathrm{K}$ dan $\mathrm{C}$ menilai tayangan visual misa termediasi secara lebih positif. Informan $\mathrm{K}$ dan $\mathrm{C}$ menghormati prosesi konsekrasi komuni di layar kaca karena misa merupakan panggilan umat Katolik. Informan C mengatakan umat perlu menyatu dan menghayati komuni batin agar menyatu dengan apa yang ditayangkan di layar kaca. Bahkan Informan $\mathrm{K}$ turut merasakan haru biru saat proses tersebut berlangsung. Menurut Informan K:

"Justru saya disitu malah nangis, anak saya yang gede juga nangis tapi semua dalam keadaan hening jadi hati saya haru biru gitu. Bukan berarti misa di gereja kurang ya. Tetapi perasaan keheningan saya lebih dapet. Arahan romo dan saat dia mengangkat hosti saya merasa ga sanggup." (Hasil wawancara pada 22 Mei 2020)

Lain halnya dengan Informan A yang mengatakan bahwa menyaksikan prosesi misa di gereja maupun live streaming tidak terlalu berbeda. Baginya live streaming hanya sebagai cara ibadah yang lain. Ia justru lebih menyukai situasi misa live streaming sebagai pengandaian proses ibadah di ruang gereja kecil yang lebih pribadi dibandingkan di gereja fisik yang besar dan kosong.

Suasana kekhusyukan lazim ingin dicapai oleh umat dalam sebuah misa. Bagi Informan $\mathrm{E}$, kekhusyukan misa live streaming bisa ia raih namun tidak maksimal meski persiapan diri dan situasi agar menyerupai misa fisik sudah dilakukan. Untuk menciptakan kondisi kekhusyukan maka sebelum misa dimulai, Informan E, K, dan C menyiapkan benda-benda gereja di atas meja, seperti patung salib, patung Bunda Maria, lilin, bunga, serta mengikuti petunjuk misa live streaming yang ada. Selain menyiapkan situasi dan kondisi, Informan K dan C merasa lebih khusyuk karena jumlah peserta misa yang lebih sedikit dibandingkan misa di gereja. Bahkan Informan $\mathrm{C}$ melihat khotbah pastor melalui media TVRI membantu umat untuk tetap di rumah dan mencegah penularan virus COVID-19.

Menurut Informan S, kekhusyukan misa live streaming terkait beberapa faktor yaitu keberadaan orang lain, keadaan saat menonton, dan infrastruktur sinyal internet. Informan $\mathrm{S}$ berujar:

"Ya tergantung juga sih, di gereja bisa khusuk juga kalau posisi nya di dalem, kalau posisinya diluar emang gak bakal dapet lah ya. Kalau ini 50:50 juga kadang-kadang 
namanya sinyal di parung panjang naik turun kan. Tiba-tiba nge-freeze atau lompat kemana." (Hasil wawancara pada 22 Mei 2020)

Ketika melakukan misa, Informan $\mathrm{S}$ harus memisahkan diri dengan anggota keluarganya yang lain agar lebih berkonsentrasi. Pasalnya jika melakukan misa livestreaming bersama, anggota keluarganya kerap mengomentari kekurangan tayangan misa yang berlangsung. Bagi Informan J, kekhusyukan dan fokus sulit diraih selama ia mengikuti misa live streaming karena banyak pengalih perhatian. Sementara Informan A tidak merasakan perbedaan berarti antara keduanya.

Sebagai instrumen ritual, Informan E menilai misa live streaming sebagai sarana mendengarkan pembacaan injil dari kitab suci karena baginya kebutuhan berdoa bisa ia lakukan sendiri. Bagi Informan S dan A, misa live streaming telah menggenapi kekosongan rutinitas ke gereja setiap minggu. Informan A merasa telah menjalankan kewajibannya dan tidak memiliki utang kehadiran di gereja. Bagi J, misa live streaming malah menimbulkan rasa kerinduan karena ada hal-hal yang tidak bisa dilakukan selama misa daring, seperti prosesi komuni dan salam damai.

Mayoritas informan melihat misa termediasi internet atau TV sebagai sebuah hal yang baik. Informan $\mathrm{E}, \mathrm{J}$, dan $\mathrm{S}$ menilai misa live streaming bisa membantu umat yang berhalangan menghadiri misa di gereja oleh karena satu lain hal. Informan $\mathrm{C}$ juga menilai misa perlu terus disiarkan jika kondisi kembali normal karena berkaca belasan tahun yang lalu, ia ingat TVRI pernah menyiarkan program ibadah Mimbar Agama Katolik.

Meskipun Informan $\mathrm{J}$ dan $\mathrm{E}$ mendukung misa live streaming terus dilanjutkan, mereka secara pribadi merasa sedih karena tidak ada perjumpaan dan interaksi dengan Pastor yang dikenal dan juga umat lain. Sementara Informan K berharap jika kondisi sudah normal, umat kembali misa di Gereja sebagai bentuk pelaksanaan kewajiban dan berkumpul dengan saudara dan keluarga dalam iman, meski ia tidak menafikan efek positif kondisi pandemi yaitu mengumpulkan semua anggota keluarganya di rumah dan sama-sama beribadah.

Di lain pihak, A melihat dengan lebih ekstrem. Menurut dia, jika physical distancing sudah berakhir, umat sebenarnya tidak perlu lagi misa di gereja karena bisa dimediasi oleh YouTube. Informan A mengatakan:

"Kalo gue bukan soal penggunaan sih, kalau gue mikirnya kalau next-nya, udah normal lagi, berarti gak usah ke gereja lagi, dari YouTube aja bisa. Gue rasa gereja perlu melihat misa online sebagai sebuah alternatif bagi orang-orang yang gak bisa hadir entah karena alasan sakit atau apalah." (Hasil wawancara pada 22 Mei 2020)

\section{Diskusi}

Misa merupakan kewajiban atau setidaknya kebutuhan penganut agama Katolik baik dalam kondisi normal ataupun phsyical distancing di kala pandemi COVID-19. Live streaming atau menonton misa dari TVRI merupakan solusi paling masuk akal. Seperti disebutkan di atas, streaming merupakan proses transfer data atau informasi dari satu pengguna ke pengguna lain, baik melalui aplikasi tertentu atau secara langsung (Baktikominfo, 2019). Dalam hal ini Youtube dan atau TVRI menjadi wadah pentransferan layanan ibadah dari gereja 
Hasian Laurentius Tonggo, Irwansyah:

Mediated Catholic Mass During the COVID-19 Pandemic: On Communication, Technology and Spiritual Experience

Misa Katolik Termediasi Saat Pandemi COVID-19: Antara Komunikasi, Teknologi, dan Pengalaman Spiritual

ke umat. Umat tinggal memilih satu dari puluhan kanal YouTube gereja yang menyiarkan misa sesuai dengan preferensinya masing-masing, misalnya jadwal yang lebih fleksibel atau kesesuaian keanggotaan gereja sebagaimana dipaparkan Informan K, C, dan S. Sementara siaran TVRI memiliki jadwal yang pasti namun tidak memerlukan koneksi internet sehingga cara ini lebih terjangkau masyarakat seperti yang ditunjukkan Informan C.

Misa live streaming memungkinkan perilaku ibadah yang tidak mungkin dilakukan dalam misa fisik seperti berpindah kanal di tengah misa yang sedang berlangsung jika live streaming yang diikuti kurang menarik. Fenomena ini disebut church-hopping, yaitu bilamana umat berpindah dari satu gereja atau keimanan ke yang lain (Beneke, 2010). Penyiaran ini memberi kemudahan kepada umat Katolik untuk mencari tayangan misa yang sesuai dengan keinginan mereka, seperti yang dilakukan oleh Informan E dan A ketika misa yang ia tonton kurang cocok baginya. Sementara itu, Informan $\mathrm{J}$ memilih live streaming misa dengan kualitas audiovisual lebih bagus. Berdasarkan RSST, para informan memilih media atau tayangan misa termediasi yang sesuai dengan makna teknologi media bagi mereka masing-masing.

\section{Pengalaman}

Meskipun misa live streaming memberi kemudahan kepada gereja dan umat, namun bukan berarti pengalaman ibadah itu berjalan mulus. Kadang kala terjadi hambatan eksternal, misalnya sambungan internet yang kurang baik atau suara-suara yang menganggu momen ibadah. Hal ini dialami oleh Informan S dan $\mathrm{J}$ yang merasa terganggu dengan hal-hal tersebut saat menonton misa. Kemudian keniscayaan internet pada teks media tidak kompatibel dengan niat informan untuk mencapai kontemplasi soliter atau kekhusyukan (Frost \& Youngblood, 2014; Hagenbuch, 2020). Maka tidak mengherankan terdapat kelompok yang menyatakan misa live streaming gagal memberi kesan yang sama dibandingkan misa di gereja secara langsung. Teks visual tidak cukup memancarkan aura keberadaan sehingga gagal menimbulkan pengalaman sakral. Informan S menilai kualitas prosesi simbolik misa yang sakral berubah menjadi hanya sekadar tontonan. Ironisnya, meski telah melakukan persiapan khusus, misa live streaming tetap menghilangkan perasaan solitari dan refleksi kebatinan sebagaimana dikatakan Informan E, J, dan S. Hal ini sejalan dengan apa yang dikatakan Zordan (2014) bahwa kualitas partisipasi umat dalam misa yang disiarkan memengaruhi diri masing-masing orang untuk beribadah.

Sebaliknya, Informan $\mathrm{K}$ dan $\mathrm{C}$ melihat misa termediasi mampu memberi pengalaman misa yang sama bahkan lebih khusyuk dibandingkan dengan misa di gereja. Informan $\mathrm{K}$ mengungkapkan bahwa misa termediasi yang dilakukan di dalam rumah mampu meningkatkan persatuan antarumat, meski umat dalam konteks ini adalah anggota keluarga Informan $\mathrm{K}$ sendiri. Hal ini erat kaitannya dengan lokasi dan peserta misa yang lebih sedikit serta merupakan anggota keluarga informan sehingga bisa menciptakan konsolidasi dan keanggotaan umat seperti yang dikatakan Campbell \& DeLashmutt (2014). Informan K dan C juga berhasil mendapatkan kontemplasi dan refleksi kebatinan dari teks media yang ditampilkan asal dibekali niat, kesadaran, dan penghormatan pada misa. Informan 
A bahkan memiliki sikap lebih ekstrem karena menganggap misa live streaming mampu menggantikan misa fisik sepenuhnya. Ini merupakan perwujudan bahwa aktivitas daring dan luring bisa terintegrasi (H. A. Campbell \& DeLashmutt, 2014). Meski begitu berdasarkan RSST, muncul sikap informan yang beragam mengenai misa termediasi ini, ada yang menunjukkan sikap menolak, menerima atau menegosiasikan penggunaan teknologi yang berkaitan dengan kode moral, nilai, kepercayaan, dan tradisi umat katolik.

Dalam mengikuti misa streaming dari kanal youtube, Informan E, A, S, dan $\mathrm{K}$ mengakui tidak bisa melakukan interaksi karena fitur tersebut dinonaktifkan. Ini seperti yang dinyatakan sebagai religion-online di mana struktur komunikasi one-to-many yang terkontrol dipertahankan (Frost \& Youngblood, 2014). Keterangan para informan menyatakan bahwa mereka tidak bisa berbagi, berkomentar, dan menyukai selama live streaming berlangsung. Hal itu bisa saja dilakukan untuk menjaga konsentrasi khalayak. Dengan demikian, keputusan gereja untuk mematikan fitur-fitur tersebut membuat konsep social affordance tidak berlaku padahal social affordance membuat khalayak menyadari opini dan keberadaan orang lain di dunia daring (Kavanaugh et al., 2014) sementara dalam konteks di sini tidak ada. Hal ini ditunjukkan Informan J dan E yang merasa ketidakhadiran umat lain membuat mereka merasa tidak nyaman dengan misa secara live streaming. Selain itu, ada kalanya meski fitur yang mendukung social affordance di kanal YouTube diaktifkan, informan tetap memilih untuk tidak melakukan interaksi seperti berbagi, berkomentar, atau menyukai tayangan misa. Ini dialami oleh Informan A dan E karena mereka menganggap ini tidak perlu.

\section{Pemanfaatan Teknologi Kedepan}

Mayoritas informan setuju jika misa termediasi sebaiknya terus dilanjutkan gereja saat pandemi COVID-19 berakhir karena membantu umat yang berhalangan hadir ikut misa di gereja, serta sebagai jalan menghidupkan kembali kehadiran Gereja Katolik di media arus utama seperti televisi. Seperti tertulis di atas, Informan A bahkan mengatakan bahwa misa di gereja diganti saja seterusnya lewat YouTube. Ide tersebut berdasarkan refleksi pengalaman informan, dan jika melihat misa sebagai kegiatan ritual komunikasi, misa termediasi menitikberatkan pada pengukuhan masyarakat dan representasi kepercayaan yang sama tanpa harus berada di satu lokasi bersamaan (Radford, 2005). Meski termediasi, pemahaman praktik agama sebenarnya tetap sama, yaitu sebagai upaya menghubungkan manusia dengan sesuatu yang transenden melalui pengorganisasian hubungan sosial keduanya, serta menyatukan dan mengikat umat satu dengan yang lain (H. A. Campbell \& DeLashmutt, 2014; Radford, 2005). Pentingnya hubungan dan relasi sosial ini diusulkan oleh informan $\mathrm{K}$ sebagai kewajiban umat untuk kembali memusatkan aktivitas ke gereja fisik saat pandemi COVID-19 berakhir.

Selain itu dari pengalaman para informan, misa live streaming melalui kanal Youtube tidak mutlak sejalan dengan Hukum Media Digital (Logan, 2019), yakni lemahnya interaktivitas: berbagi, berkomentar, dan menyukai serta karakter one-to-many communication dari religion-online bertentangan dengan komunikasi 
Hasian Laurentius Tonggo, Irwansyah:

Mediated Catholic Mass During the COVID-19 Pandemic: On Communication, Technology and Spiritual Experience

Misa Katolik Termediasi Saat Pandemi COVID-19: Antara Komunikasi, Teknologi, dan Pengalaman Spiritual

dua arah pada Hukum Media Digital. Walaupun ada pertentangan pada poin pertama dan ketiga Hukum Media Digital dengan praktik saat ini, poin kedua tetap berlaku karena para informan secara mayoritas memilih menggunakan media digital daripada televisi konvensional. Sementara ketersediaan tayangan misa di televisi nasional bisa mensejajarkan televisi konvensional dengan media digital khususnya di kala pandemi. Informan $\mathrm{C}$ merupakan bukti nyata bahwa televisi tidaklah kuno meski sekarang adalah era digital. Menurut Informan C, Ia lebih nyaman mengikuti misa melalui sarana televisi karena lebih mudah diakses.

\section{Simpulan}

Secara keseluruhan, studi ini berupaya mendeskripsikan pengalaman umat Katolik yang menghadiri misa mediasi selama periode social distancing akibat pandemi COVID-19. Pengalaman umat bisa berbeda antara satu dengan yang lain karena terdapat faktor-faktor yang dapat mempengaruhinya, yaitu media yang digunakan, situasi internal dan eksternal umat ketika menghadiri misa, kemampuan atau ketidakmampuan berinteraksi, konsistensi media teks, dan bagaimana massa yang dimediasi entah bagaimana mereduksi beberapa simbol sakral menjadi hanya tontonan. Namun, disepakati bahwa misa yang dimediasi adalah sesuatu yang perlu dilakukan selama pandemi karena dan bisa dilanjutkan bahkan setelah pandemi selesai. Berangkat dari tulisan ini, penelitian lain dapat melihat hal-hal di luar pengalaman jemaat, misalnya implikasi mediasi misa dan otoritas gereja pada orang-orang dalam kelompok umur tertentu, atau penyampaian misa yang dimediasi dari perspektif gereja.

Penelitian ini ingin berharap bisa memberi rekomendasi akademis, berupa meingkatkan khazanah pengetahuan tentang ibadah termediasi, khususnya di ranah daring dengan sentuhan konteks pandemi. Kemudian, secara praktis, penelitian ini dapat menjadi acuan bagi gereja untuk meningkatkan kualitas misa daring, memperluas jangkauan, agar umat bisa lebih menikmati atau memahami upaya spiritualitas misa yang ditayangkan. Kondisi pandemi yang masih berlangsung membuat pembahasan pengalaman ibadah termediasi ini masih menjadi topik yang muncul-tenggelam di masyarakat beragama saat ini.

\section{Ucapan Terima Kasih}

Penulis ingin mengucapkan terima kasih sebesar-besarnya pada pihakpihak yang telah membantu pelaksanaan penelitian ini, khususnya para informan, dosen, dan rekan mahasiswa di Program Pascasarjana Ilmu Komunikasi Universitas Indonesia.

\section{Daftar Pustaka}

Alshenqeeti, H. (2014). Interviewing as a Data Collection Method: A Critical Review. English Linguistics Research, 3(1), 39-45. https://doi.org/10.5430/elr.v3n1p39 
Baktikominfo. (2019). Pengertian Streaming Serta Jenis dan Penerapannya. https://www.baktikominfo.id/en/informasi/pengetahuan/pengertian_stream ing_serta_jenis_dan_penerapannya-1065

Beneke, C. (2010). The free market and the founders' approach to church-state relations. Journal of Church and State, 52(2), 323-352. https://doi.org/10.1093/jcs/csq053

Bills, A. (2017). Virtual Catholicism [University of New Hampshire]. In Master's Theses and Capstones. https://scholars.unh.edu/thesis/933

Cabiddu, F., Carlo, M. De, \& Piccoli, G. (2014). Social media affordances: Enabling customer engagement. Annals of Tourism Research, 48, 175192. https://doi.org/10.1016/j.annals.2014.06.003

Campbell, H. (2020). Religion in Quarantine: The Future of Religion in a PostPandemic

World. https://doi.org/https://doi.org/10.21423/religioninquarantine

Campbell, H. A. (2010). When religion meets new media. In When Religion Meets New Media. https://doi.org/10.4324/9780203695371

Campbell, H. A., \& DeLashmutt, M. W. (2014). Studying Technology and Ecclesiology in Online Multi-Site Worship. Journal of Contemporary Religion, 29(2), 267-285. https://doi.org/10.1080/13537903.2014.903662

Christensen, M., Welch, A., \& Barr, J. (2017). Husserlian Descriptive Phenomenology: A review of intentionality, reduction and the natural attitude. Journal of Nursing Education and Practice, 7(8), 113. https://doi.org/10.5430/jnep.v7n8p113

Chrisyantia, K. (2020). Mulai 29 Maret, Misa Disiarkan Langsung Di TVRI. 2020. https://www.hidupkatolik.com/2020/03/23/43300/mulai-29-maretmisa-disiarkan-langsung-di-tvri

Frost, J. K., \& Youngblood, N. E. (2014). Online Religion and Religion Online: Reform Judaism and Web-Based Communication. Journal of Media and Religion, 13(2), 49-66. https://doi.org/10.1080/15348423.2014.909190

Giorgi, A. (2019). Mediatized catholicism-minority voices and religious authority in the digital sphere. Religions, 10(8), 1-22. https://doi.org/10.3390/rel10080463

Guo, Y. R., Cao, Q. D., Hong, Z. S., Tan, Y. Y., Chen, S. D., Jin, H. J., Tan, K. Sen, Wang, D. Y., \& Yan, Y. (2020). The origin, transmission and clinical therapies on coronavirus disease 2019 (COVID-19) outbreak- A n update on the status. Military Medical Research, 7(1), 1-11. https://doi.org/10.1186/s40779-020-00240-0

Guzek, D. (2015). Discovering the Digital Authority: Twitter as Reporting Tool for Papal Activities. Online - Heidelberg Journal of Religions on the Internet, 9. https://doi.org/10.11588/rel.2015.0.26251

Hagenbuch, W. (2020). Won't you be my neighbor? creating an interconnected onsite and online christian community [Lancaster Theological Seminary]. https://search.proquest.com/docview/2404622092? accountid=17242

Hidayat, D. (2009). Dikotomi Kualitatif - Kuantitatif Dan Varian Paradigmatik Dalam Penelitian Kualitatif. Scriptura, 2(2), 81-94. https://doi.org/10.9744/scriptura.2.2.81-94 
Hasian Laurentius Tonggo, Irwansyah:

Mediated Catholic Mass During the COVID-19 Pandemic: On Communication, Technology and Spiritual Experience

Misa Katolik Termediasi Saat Pandemi COVID-19: Antara Komunikasi, Teknologi, dan Pengalaman Spiritual

Hidayat, M. A. (2017). Ibadat, The Body and Identity: Islamic Rituals and the Construction of Muslim Identity. The Journal of Society \& Media, 1(2), 118. https://doi.org/http://dx.doi.org/10.26740/jsm.v1n2.p1-17

Humeira, B., \& Sarwono, B. (2019). Religious-social shaping of technology approach to internet use by an urban islamic group in Indonesia. Jurnal Komunikasi: Malaysian Journal of Communication, 35(4), 69-82. https://doi.org/10.17576/JKMJC-2019-3504-05

Isiko, A. P. (2020). Religious construction of disease : An exploratory appraisal of religious responses to the COVID-19 pandemic in Uganda. 12(September), 77-96. https://doi.org/10.5897/JASD2020.0573

Kavanaugh, A., Ahuja, A., Gad, S., Neidig, S., Pérez-Quiñones, M. A., Ramakrishnan, N., \& Tedesco, J. (2014). (Hyper) local news aggregation: Designing for social affordances. Government Information Quarterly, 31(1), 30-41. https://doi.org/10.1016/j.giq.2013.04.004

Landridge, D. (2007). Phenomenological psychology: Theory, research and practice. Pearson.

Lim, A. E. H. (2019). Between the sea and the shore: mediating the Nine Emperor Gods Festival in Singapore. Journal of Contemporary Religion, 34(1), 117-134. https://doi.org/10.1080/13537903.2019.1585125

Lim, A. E. H. (2020). Live Streaming and Digital Stages for the Hungry Ghosts and Deities. Religions, 11(7), 367. https://doi.org/10.3390/rel11070367

Logan, R. K. (2019). Understanding humans: The extensions of digital media. Information (Switzerland), 10(10). https://doi.org/10.3390/info10100304

Lövheim, M. (2011). Mediatisation of religion: A critical appraisal. Culture and Religion, 12(2), 153-166. https://doi.org/10.1080/14755610.2011.579738

Mikos, L. (2016). Digital Media Platforms and the Use of TV Content: Binge Watching and Video-on-Demand in Germany. Media and Communication, 4(3), 154. https://doi.org/10.17645/mac.v4i3.542

Nduka, E. L., \& McGuire, J. (2017). The Effective Use of New Media in Disseminating Evangelical Messages Among Catholic College Students. Journal of Media and Religion, 16(3), 93-103. https://doi.org/10.1080/15348423.2017.1361707

Neuman, W. L. (2014). Social Research Methods: Qualitative and Quantitative Approaches (7th ed.). Pearson Education Limited.

Pradsmadji, S. I., \& Irwansyah, I. (2019). Pengalaman dan Pandangan Khalayak Pegiat Sinema Non-Produksi Terkait Teknologi 3D Sebagai Pendukung Saluran Komunikasi Film. Jurnal Komunikasi, 11(2), 141-154. https://doi.org/10.24912/jk.v11i2.4060

Putri, R. D. (2020). Kronologi Penularan Pasien Positif Corona COVID-19 di Indonesia. https://tirto.id/kronologi-penularan-pasien-positif-corona-covid19-di-indonesia-eD6x

Radford, G. P. (2005). On the Philosophy of Communication. Thomson Wadsworth. http://books.google.com/books?id=1zliAAAAMAAJ.

Ratcliff, A. J., McCarty, J., \& Ritter, M. (2017). Religion and New Media: A Uses and Gratifications Approach. Journal of Media and Religion, 16(1), 1526. https://doi.org/10.1080/15348423.2017.1274589 
Shereen, M. A., Khan, S., Kazmi, A., Bashir, N., \& Siddique, R. (2020). COVID19 infection: Origin, transmission, and characteristics of human coronaviruses. Journal of Advanced Research, 24, 91-98. https://doi.org/10.1016/j.jare.2020.03.005

Wildman, W. J., Bulbulia, J., Sosis, R., \& Schjoedt, U. (2020). Religion and the COVID-19 pandemic. Religion, Brain and Behavior, 10(2), 115-117. https://doi.org/10.1080/2153599X.2020.1749339

Zordan, D. (2014). Screening Piety, Invoking Fervour: The Strange Case of Italy's Televised Mass. Journal of Religion, Media \& Digital Culture, $3(1), 56-83$. 